\title{
Bloqueio Combinado para Analgesia de Parto: A Adição de Sufentanil ao Anestésico Local Influencia o Apgar dos Recém-Nascidos?*
}

Combined Spinal-Epidural for Labor Analgesia: Does the Addition of Sufentanil to the Local Anesthetic Influence Apgar Scores of the Newborns?

\author{
Domingos Dias Cicarelli, TSA ${ }^{1}$, Renata Veloso Silva, TSA ${ }^{1}$, Elke Frerichs, TSA ${ }^{1}$, Marcelo Lacava Pagnocca, TSA
}

\section{RESUMO}

Cicarelli DD, Silva RV, Frerichs E, Pagnocca ML - Bloqueio Combinado para Analgesia de Parto: A Adição de Sufentanil ao Anestésico Local Influencia o Apgar dos Recém-Nascidos?

JUSTIFICATIVA E OBJETIVOS: O bloqueio combinado (BC) é uma técnica muito utilizada em anestesia obstétrica. Porém não há na literatura padronização com relação à técnica, doses e anestésicos utilizados, além da controvérsia sobre a possibilidade da adição do opióide ao anestésico local causar bradicardia fetal e alteração de sua vitalidade. O objetivo deste estudo foi identificar as técnicas e anestésicos utilizados no Serviço de Anestesiologia do Hospital Universitário da Universidade de São Paulo (USP) e avaliar se a utilização de sufentanil associado ao anestésico local no BC altera o Apgar dos recém-nascidos.

MÉTODO: Foram analisadas as fichas de anestesia em que foram realizados $B C$ para analgesia de parto durante 12 meses no Hospital Universitário da USP. Foram registrados o uso e dose de sufentanil, a via de parto utilizada e os escores de Apgar do $1^{\circ}, 5^{\circ}$ e $10^{\circ}$ minutos dos recém-nascidos.

RESULTADOS: Dos 635 BC avaliados, 307 utilizaram sufentanil e anestésico local (Grupo SUF) e 328, só anestésico local (Grupo $A L)$. Cento e vinte e sete (20\%) foram realizados através da técnica de agulha por dentro de agulha e os outros 508 (80\%) foram realizados pela técnica de duas punções. Não foi verificada diferença entre o Apgar dos grupos estudados no $1^{\circ}, 5^{\circ}$ e $10^{\circ}$ minutos.

CONCLUSÕES: O sufentanil utilizado no bloqueio combinado não alterou o Apgar dos recém-nascidos.

Unitermos: ANALGESIA, Obstétrica: parto; ANALGÉSICOS, Opióide: sufentanil; AVALIAÇÃO RECÉM-NASCIDO: Apgar; TÉCNICAS ANESTÉSICAS, Regional: combinada.

${ }^{*}$ Recebido do (Received from) Serviço de Anestesiologia do Hospital Universitário da Universidade de São Paulo (HU-USP), São Paulo, SP

1. Anestesiologista do Hospital Universitário da USP

Apresentado (Submitted) em 6 de julho de 2006

Aceito (Accepted) para publicação em 21 de fevereiro de 2007

Endereço para correspondência (Correspondence to):

Dr. Domingos Dias Cicarelli

Av. Piassanguaba, 2933/71 - Planalto Paulista

04060-004 São Paulo, SP

E-mail:dcicarelli@uol.com.br

() Sociedade Brasileira de Anestesiologia, 2007

\section{SUMMARY}

Cicarelli DD, Silva RV, Frerichs E, Pagnocca ML - Combined SpinalEpidural for Labor Analgesia: Does the Addition of Sufentanil to the Local Anesthetic Influence Apgar Scores of the Newborns?

BACKGROUND AND OBJECTIVES: Combined spinal-epidural (CSE) is a very common obstetric technique. However, the literature does not present a standardization regarding the technique, doses, and anesthetics used, besides there is also the controversy about the possibility that the addition of opioids to the local anesthetic causes fetal bradycardia and affects its vitality. The aim of this study was to identify the techniques and anesthetics used in the Anesthesiology Service of the Hospital Universitário of Universidade de São Paulo (USP) and determine whether the use of sufentanil associated with the local anesthetic affects Apgar scores of newborns.

METHODS: The anesthesiology charts of patients submitted to CSE for labor analgesia over a 12-month period at the Hospital Universitário of USP were analyzed. The use and dose of sufentanil, the type of delivery, and Apgar scores in the $1^{\text {st }}, 5^{\text {th }}$, and $10^{\text {th }}$ minutes were recorded.

RESULTS: Of the 635 CSE analyzed, 307 used sufentanil and local anesthetic (SUF Group) and 328 only local anesthetic (LA Group). One hundred and twenty-seven (20\%) were done using the needle through the needle technique and the other 508 (80\%) used the double puncture technique. There were no differences in the Apgar scores in the $1^{\text {st }}, 5^{\text {th }}$, and $10^{\text {th }}$ minutes between both groups.

CONCLUSIONS: The use of sufentanil in the combined spinalepidural did not change Apgar scores of the newborns.

Key Words: ANALGESIA, Obstetric: labor; ANALGESICS, Opioids: sufentanil; NEWBORN EVALUATION: Apgar; ANESTHETIC TECHNIQUES, Regional: combined.

\section{INTRODUÇÃO}

O bloqueio combinado (BC) é uma associação de duas écnicas anestésicas já consagradas: a raquianestesia e a anestesia peridural contínua ${ }^{1}$. Teve grande aceitação na prática anestésica pois permite a utilização de pequenas doses de anestésico local associado ou não aos opióides na raquianestesia, proporcionando menores efeitos hemodinâmicos, com a garantia da introdução de um cateter peridural caso haja a necessidade de níveis mais altos de anestesia ou maior duração do procedimento cirúrgico 1,2 . 
Foi imediata a sua indicação como técnica anestésica útil às gestantes em trabalho de parto, devido às baixas doses de anestésico local utilizado e ao grande relaxamento perineal obtido ${ }^{1,3-6}$. Muitos anestesiologistas se entusiasmaram com a evolução do trabalho de parto após a utilização desta técnica, comparativamente à peridural contínua utilizada até então ${ }^{3}$. Porém, não há na literatura padronização com relação à melhor técnica para a realização do bloqueio combinado e nem com relação às doses e anestésicos a serem utilizados. As técnicas descritas variam entre: duas punções, uma para raquianestesia e outra para a anestesia peridural, realizadas em espaços diferentes; ou a punção com a utilização da técnica agulha por dentro de agulha, em que a punção peridural é realizada inicialmente, e por dentro da agulha de peridural é introduzida a agulha de raquianestesia longa. Injeta-se o anestésico no espaço subaracnóideo e, em seguida, é introduzido o cateter peridural ${ }^{1}$. Com relação aos anestésicos utilizados, podem ser usadas a bupivacaína e a lidocaína hiperbáricas associadas ou não aos opióides (fentanil, sufentanil, morfina) ${ }^{1}$. Existem relatos controversos ${ }^{5,7,8}$ sobre a possibilidade da adição do opióide ao anestésico local ser causa de bradicardia fetal e alteração da vitalidade fetal, tendo influência no Apgar dos recémnascidos. Essa dúvida também preocupa pediatras e obstetras que questionam o uso do sufentanil na técnica anestésica e suas possíveis repercussões sobre o feto. O objetivo deste estudo foi identificar as técnicas e anestésicos utilizados no Serviço de Anestesiologia do Hospital Universitário da USP e avaliar se a utilização de sufentanil associado ao anestésico local no bloqueio combinado altera o Apgar dos recém-nascidos.

\section{MÉTODO}

Após aprovação pelo Comitê de Ética, foi realizado um estudo observacional retrospectivo, através da revisão de fichas de anestesia em que foram realizados bloqueios combinados para analgesia de parto durante 12 meses (de maio de 2004 até maio de 2005) no Hospital Universitário da USP. Foram anotados: o anestésico local (AL) utilizado na raquianestesia e sua respectiva dose, bem como a dose de sufentanil (quando utilizado) e a via de parto utilizada (parto normal, fórcipe ou cesariana). As pacientes foram divididas em dois grupos: anestésico local com sufentanil (grupo SUF) e anestésico local (grupo AL). O anestésico associado ou não ao sufentanil era escolhido de acordo com a preferência do anestesiologista responsável pelo procedimento. Os grupos foram comparados com relação ao peso, idade das pacientes, incidência de parto normal, cesariana e com fórcipe. A rotina do serviço prevê correção de hipotensão com bolus de $5 \mathrm{mg}$ de efedrina sempre que a pressão arterial sistólica for $20 \%$ inferior aos níveis basais ou inferior a 100 $\mathrm{mmHg}$. As complementações realizadas após a instalação do bloqueio combinado são realizadas com bupivacaína com vasoconstritor em bolus de $5 \mathrm{~mL}$ a $0,125 \%, 0,25 \%$ ou $0,5 \%$ de acordo com a dilatação do colo uterino.

O escore de Apgar do $1^{\circ}, 5^{\circ}$ e $10^{\circ}$ minutos dos recém-nascidos, atribuído pelo neonatologista, foi comparado entre os grupos SUF e AL através do teste de ANOVA, considerandose significativo um $p<0,05$. Foi calculado o risco relativo das pacientes que receberam sufentanil terem recém-nascidos com Apgar inferior a 7 no $1^{\circ}, 5^{\circ}$ ou $10^{\circ}$ minutos. O risco relativo foi calculado pela razão entre a incidência de Apgar menor que 7 nos recém-nascidos expostos ao sufentanil sobre a mesma incidência nos não expostos ${ }^{9}$. As vias de parto em cada grupo foram comparadas pelo teste do Quiquadrado.

\section{RESULTADOS}

Foram identificadas 698 anestesias com a utilização da técnica de bloqueio combinado, sendo que 63 pacientes (9\%) foram excluídas do estudo por falta de registros completos. Das 635 anestesias válidas, 307 anestesias tiveram adição de sufentanil ao anestésico local (grupo SUF) e $328 \mathrm{com}$ anestésico local sem sufentanil (grupo AL).

Dos 635 bloqueios combinados avaliados, 127 (20\%) foram realizados através da técnica de agulha por dentro de aguIha, realizando a peridural com agulha de Tuohy $16 \mathrm{G}$ com a técnica de perda da resistência, raquianestesia com aguIha $27 \mathrm{G}$ (116 mm, Whitacre) por dentro da agulha de peridural e passagem do cateter peridural 18G. Os outros 508 $\mathrm{BC}(80 \%)$ foram realizados pela técnica de duas punções: raquianestesia com agulha $27 \mathrm{G}$ (90 $\mathrm{mm}$, Whitacre) e no melhor espaço imediatamente superior ou inferior punção peridural com agulha 16G (técnica perda da resistência) e passagem de cateter peridural $18 \mathrm{G}$.

O grupo SUF foi composto de 307 pacientes que receberam bupivacaína hiperbárica a 0,5\% (2,5 mg) e sufentanil $(2,5 \mu \mathrm{g})$ na raquianestesia. $O$ grupo $A L$ foi composto por 328 pacientes que receberam bupivacaína hiperbárica a 0,5\% (5mg) na raquianestesia.

Os grupos não diferiram com relação à idade, sendo que a média dessa variável para o grupo $A L$ foi $23,69 \pm 5,56$ anos e para o grupo SUF foi 23,05 $\pm 5,68$ anos (teste $t$ com $p=$ $0,15)$. Com relação ao peso não houve diferença entre os grupos: $69,4 \pm 11,2 \mathrm{~kg}$ no grupo AL e $71,6 \pm 10,4 \mathrm{~kg}$ no grupo SUF (teste $t \operatorname{com~} \mathrm{p}=0,42$ ).

$\mathrm{O}$ risco relativo (RR) de uma gestante que recebeu sufentanil na sua analgesia ter um recém-nascido com Apgar de $1^{\circ}$ minuto menor que 7 foi de $0,78(95 \% \mathrm{IC}, 0,60$ a 1,02) comparada a uma gestante que só recebeu anestésico local. $O$ RR permaneceu menor que 1 nos escores de Apgar do $5^{\circ}$ minuto ( $R R=0,43 / 95 \%$ IC, 0,19 a 0,99) e $10^{\circ}$ minuto (RR $=0)$ (Tabela I).

Não foi verificada diferença significativa entre o Apgar dos grupos estudados no $1^{\circ}, 5^{\circ}$ e $10^{\circ}$ minutos (Tabela II).

Dezenove pacientes $(2,9 \%)$ evoluíram com bradicardia fetal persistente logo após a realização do BC, tendo sido sub- 
metidas à cesariana por essa razão. Entre essas pacientes, oito delas $(2,6 \%)$ pertenciam ao grupo SUF e $11(3,3 \%)$ ao grupo $\mathrm{AL}$, sem diferença estatística significativa.

Tabela I - Recém-Nascidos com Apgar Inferior a 7 no $1^{\circ}, 5^{\circ}$ e $10^{\circ}$ Minutos

\begin{tabular}{lcc}
\hline Apgar $<7$ & Grupo SUF & Grupo AL \\
\hline $1^{\circ}$ minuto & $34(11,1 \%)$ & $46(14 \%)$ \\
$5^{\circ}$ minuto & $4(1,3 \%)$ & $10(3 \%)$ \\
$10^{\circ}$ minuto & 0 & $4(1,2 \%)$ \\
Total $(\mathrm{n})$ & 307 & 328 \\
\hline
\end{tabular}

SUF - Grupo que recebeu sufentanil adicionado ao anestésico local; AL - Grupo do anestésico local.
Com relação à via de parto, no grupo SUF houve $23,4 \%$ de cesarianas, $54,1 \%$ de parto fórcipe e $22,5 \%$ de parto normal. No grupo AL foram realizadas $25 \%$ de cesarianas, $50,3 \%$ de parto fórcipe e $24,7 \%$ de parto normal (Tabela III), sem diferença estatística significativa pelo teste do Qui-quadrado.

Na tabela IV pode-se observar o tempo após a realização do $\mathrm{BC}$ até o nascimento, a duração da anestesia, incidência de hipotensão arterial nos grupos e a necessidade de complementação do bloqueio. Houve diferença significativa entre os grupos com relação à duração da anestesia após a dose inicial, com maior duração no grupo do sufentanil, assim como houve menor incidência de hipotensão e menor necessidade de complementação também no grupo do sufentanil (diferença significativa).

Cinco pacientes $(0,7 \%)$ apresentaram obstrução do cateter peridural ou falha na complementação pelo cateter, seis pacientes $(0,9 \%)$ tiveram punção inadvertida de dura-máter,

Tabela II - Média e Moda do Apgar no $1^{\circ}, 5^{\circ}$ e $10^{\circ}$ Minutos nos Grupos Sufentanil e Anestésico Local

\begin{tabular}{lccc}
\hline Apgar (média \pm DP / moda) & Grupo SUF & Grupo AL & $p$ \\
\hline $1^{\circ}$ minuto & $8,18 \pm 1,61 / 9$ & $7,77 \pm 1,82 / 9$ & 0,08 \\
$5^{\circ}$ minuto & $9,29 \pm 0,73 / 9$ & $8,97 \pm 1,05 / 9$ & 0,35 \\
$10^{\circ}$ minuto & $9,59 \pm 0,54 / 10$ & $9,40 \pm 0,88 / 10$ & 0,46 \\
\hline
\end{tabular}

SUF - Grupo que recebeu sufentanil adicionado ao anestésico local; AL - Grupo do anestésico local. $p$ - ANOVA.

Tabela III - Vias de Parto Utilizadas nos Dois Grupos

\begin{tabular}{lccc}
\hline Via de Parto & Grupo SUF & Grupo AL & $\mathrm{p}$ \\
\hline Normal & $69(22,5 \%)$ & $81(24,7 \%)$ & $0,45^{\star}$ \\
Fórcipe & $166(54,1 \%)$ & $165(50,3 \%)$ & $0,35^{\star}$ \\
Cesariana & $72(23,4 \%)$ & $82(25 \%)$ & $0,70^{\star}$ \\
Total $(\mathrm{n})$ & 307 & 328 & 635 \\
\hline
\end{tabular}

SUF - Grupo que recebeu sufentanil adicionado ao anestésico local; AL - Grupo do anestésico local.

* $p$ - Qui-quadrado.

Tabela IV - Diferenças entre os Grupos Estudados com Relação ao Tempo após o BC até o Nascimento, Duração da Anestesia, Incidência de Hipotensão Arterial e Necessidade de Complementação

\begin{tabular}{lccc}
\hline Características & Grupo SUF (307) & Grupo AL (328) & p \\
\hline Tempo após BC até o nascimento (min) & $70,1 \pm 35,3$ & $69,7 \pm 24,8$ & 0,77 \\
Duração da anestesia (min) & $88,2 \pm 25,3$ & $66,4 \pm 17,3$ & $<0,01$ \\
Hipotensão arterial & $59(19 \%)$ & $138(42 \%)$ & $<0,01$ \\
Complementação & $84(27 \%)$ & $172(52 \%)$ & $<0,01$ \\
\hline
\end{tabular}

SUF - Grupo que recebeu sufentanil adicionado ao anestésico local; AL - Grupo do anestésico local. 
todas evoluindo com cefaléia por hipotensão liquórica e necessitando de tampão sangüíneo autólogo (blood-patch) para tratamento. Uma paciente $(0,16 \%)$ evoluiu com quadro compatível com meningite asséptica.

\section{DISCUSSÃO}

A influência negativa do sufentanil, utilizado no BC, sobre o Apgar dos recém-nascidos não foi comprovada por este estudo.

O escore de Apgar menor que 7 é considerado indicativo de asfixia perinatal pelos pediatras, sendo este o racional para a escolha deste valor de Apgar para determinar sofrimento fetal ou não ${ }^{9-11}$. O risco relativo das gestantes que receberam sufentanil em sua anestesia apresentarem recém-nascidos com Apgar inferior a 7 foi menor que 1, não indicando risco aumentado para essas pacientes ${ }^{9}$. Esse resultado é ratificado por Lo WK e col. ${ }^{5}$ que também não encontraram diferença na evolução dos recém-nascidos após o uso subaracnóideo de sufentanil $10 \mu \mathrm{g}$ com bupivacaína $2,5 \mathrm{mg}$ comparado ao uso isolado de bupivacaína $2,5 \mathrm{mg}$. Outro autor ${ }^{4}$ relatou que o uso de fentanil $(100 \mu \mathrm{g})$ na raquianestesia não alterou a evolução dos recém-nascidos. Vertommen e col. 12 afirmaram que o sufentanil $(30 \mu \mathrm{g})$ utilizado na peridural pode ser detectado no plasma de até $12 \%$ dos recém-nascidos. Porém, mesmo esses recém-nascidos, não apresentaram alteração da vitalidade. Esse fato é confirmado por Scherer e col. ${ }^{13}$, que utilizaram sufentanil $(50 \mu \mathrm{g})$ peridural não observando efeitos deletérios sobre os RN.

Um efeito freqüentemente atribuído ao uso dos opióides associados ao anestésico local no BC é a bradicardia fetal observada imediatamente após a realização da analgesia. As explicações são diversas: o alívio muito rápido da dor diminuiria a concentração de epinefrina circulante ${ }^{14}$, a paciente perderia o efeito tocolítico da epinefrina, evoluindo com hipertonia uterina e bradicardia fetal ${ }^{8,14-16}$. D'Angelo e col. ${ }^{17}$ afirmaram que o uso do sufentanil não está associado à hipertonia uterina, e que a bradicardia fetal observada deve ser devida à hipotensão arterial materna após o BC. No estudo realizado, a prevalência de bradicardia fetal persistente, levando à indicação de cesariana como via de parto, foi de $2,9 \%$, variando na literatura de $5 \%$ a $8 \%{ }^{18}$. Porém, não se observou relação com o uso do sufentanil, sendo que um número menor de pacientes no grupo SUF $(2,6 \%)$ apresentou bradicardia comparativamente ao grupo $\mathrm{AL}$ (3,3\%). Esta observação leva a crer que a afirmação de D'Angelo e col. deve ser a mais provável explicação para este fato.

Os resultados evidenciaram que a duração do $\mathrm{BC}$ quando se acrescenta sufentanil ao anestésico local é maior do que quando realizado somente com anestésico local. Esse fato é corroborado por resultados de outros autores, embora a duração neste estudo tenha sido superior ${ }^{19}$. O grupo submetido ao BC somente com anestésico local também teve prevalência maior de hipotensão arterial logo após a instalação do bloqueio, pois a dose de anestésico local utiliza- da neste grupo foi maior que no grupo do sufentanil. Aparentemente, esse fato não influenciou o escore de Apgar, já que qualquer hipotensão arterial era prontamente corrigida com efedrina. A necessidade maior de complementação do bloqueio no grupo do anestésico local é compatível com o resultado encontrado da menor duração da anestesia neste grupo. A influência desse fato no escore de Apgar dos recém-nascidos também parece improvável, já que o tempo de anestesia no grupo do $A L$ foi muito próximo ao tempo decorrido após o $\mathrm{BC}$ até o nascimento. Logo, a necessidade de complementação, apesar de ser maior no grupo AL, ocorreu próximo ao momento do nascimento ou depois deste, com doses pequenas de bupivacaína ( $5 \mathrm{~mL}$ a $0,5 \%$ com vasoconstritor).

O tempo decorrido entre a instalação do BC até o nascimento foi semelhante entre os dois grupos. Este fato leva a crer que o sufentanil não é o responsável por uma evolução mais rápida do trabalho de parto. Na literatura, existem resultados controversos que sempre comparam o $\mathrm{BC}$ com a peridural clássica. Tsen e col. ${ }^{3}$ encontraram evolução mais rápida do trabalho de parto no grupo do $\mathrm{BC}$, resultado este não confirmado por Norris e col. ${ }^{18}$.

Não houve diferença entre as técnicas utilizadas para realização do $\mathrm{BC}$ com relação às complicações observadas. $\mathrm{A}$ prevalência de cefaléia pós-punção inadvertida de duramáter foi de $0,9 \%$ no estudo, dado comparável com os resultados de outros autores que relatam de $0,82 \%{ }^{1}$ a $2,3 \%{ }^{4}$. Com relação à meningite asséptica, observou-se um caso em 635 estudados $(0,16 \%)$. Na literatura, Wee e col. ${ }^{20}$ relataram dois casos em 1.500 pacientes estudadas (0,13\%). Alguns autores atribuem aumento no número de relatos de meningite asséptica após a introdução da técnica do $B C{ }^{1,12,20-22}$, principalmente quando a técnica utilizada para realização do $\mathrm{BC}$ é a técnica de agulha por dentro de agulha. No caso observado no presente estudo, a técnica utilizada para o $\mathrm{BC}$ foi da agulha por dentro de agulha.

Algumas críticas podem ser feitas a este estudo. Ele foi retrospectivo, podendo ter ocorrido falta de uniformidade no registro dos dados coletados. Além disso, sempre que o pediatra reanimava um $\mathrm{RN}$ com Apgar baixo no primeiro minuto, ele indagava sobre a presença de opióide na anestesia. Logo, existe a possibilidade de um viés de aferição, ou seja, os pediatras podem ter classificado com Apgar mais baixo os recém-nascidos de mães que receberam sufentanil no BC. Porém, este possível viés tenderia a classificar com vitalidade menor os $\mathrm{RN}$ de mães que receberam sufentanil, e levar à conclusão sobre a influência negativa do sufentanil no Apgar dos recém-nascidos. Este viés pode ser desprezado uma vez que esta conclusão não foi evidenciada por este trabalho. Ainda assim, existe a possibilidade da presença de variáveis de confusão, ou seja, outros fatores além do fator estudado causando baixo Apgar. Qualquer gestante que apresentasse alteração da vitalidade fetal interpretada como sofrimento fetal após a instalação do BC era submetida à cesariana. Como o índice de cesarianas não 
diferiu entre os grupos, foi possível concluir que a probabilidade de alguma variável de confusão ter comprometido o resultado foi mínima.

De acordo com os resultados, não foi possível atribuir ao sufentanil qualquer alteração no escore de Apgar dos recém-nascidos, bem como qualquer influência na bradicardia fetal observada após a instalação do BC.

\section{Combined Spinal-Epidural for Labor Analgesia: Does the Addition of Sufentanil to the Local Anesthetic Influence Apgar Scores of the Newborns?}

Domingos Dias Cicarelli, TSA, M.D.; Renata Veloso Silva, TSA, M.D.; Elke Frerichs, TSA, M.D.; Marcelo Lacava Pagnocca, TSA, M.D.

\section{INTRODUCTION}

The combined spinal-epidural (CSE) is an association of two well-known anesthetic techniques: spinal anesthesia and continuous epidural anesthesia ${ }^{1}$. It is widely accepted because it allows the use of small doses of local anesthetic associated or not with opioids in spinal anesthesia, with reduced hemodynamic effects and the guarantee of an epidural catheter in case higher levels of anesthesia are needed or the procedure lasts longer ${ }^{1,2}$. Its indication as an anesthetic technique for labor was immediate due to the low doses of local anesthetic used and the great perineal relaxation obtained ${ }^{1,3-6}$. Several anesthesiologists were excited with the evolution of labor with this technique when compared with the continuous epidural anesthesia ${ }^{3}$. However, one cannot find in the literature a standardization regarding the better technique for the combined spinal-epidural, the doses, and the drugs. The techniques described vary between: two punctures in different spaces, one for the spinal anesthesia and the other for the epidural anesthesia; or the needle through needle technique, in which the epidural puncture is done first and a long spinal anesthesia needle is introduced through the epidural needle. The anesthetic is injected in the subarachnoid space, followed by the introduction of the epidural catheter ${ }^{1}$. Regarding the anesthetic drugs used, hyperbaric bupivacaine and lidocaine, associated or not with opioids (fentanyl, sufentanil, morphine), ${ }^{1}$ can be used. Reports in the literature on the possibility of the addition of opioids to the local anesthetic causing fetal bradycardia, changing fetal vitality, and influencing Apgar scores of the newborns are controversial ${ }^{5,7,8}$. This is also a source of concern for pediatricians and obstetricians who question the use of sufentanil in the anesthesia and its possible repercussions on the fetus.

The objective of this study was to identify the techniques and anesthetics used by the Anesthesiology Service of the Hos- pital Universitário of USP and to evaluate whether the use of sufentanil associated with the local anesthetic on the combined spinal-epidural could affect Apgar scores of the newborns.

\section{METHODS}

After approval by the Ethics Committee, a retrospective, observational study was undertaken. The anesthesiology charts of patients who underwent combined spinal-epidural for labor analgesia over a 12-month period (from May, 2004 to May, 2005) at the Hospital Universitário of USP were reviewed. The following data were recorded: local anesthetic (LA) used in the spinal anesthesia and the dose, as well as the dose of sufentanil (when it was used), and the type of delivery (normal delivery, forceps, or cesarean section). Patients were divided in two groups: local anesthetic with sufentanil (SUF group) and local anesthetic (LA group). The anesthetic, associated with sufentanil or not, was chosen by the anesthesiologist responsible for the procedure according to his preference. Both groups were compared regarding weight, age, and incidence of normal delivery, cesarean section, and forceps. As per the routine of the service, episodes of hypotension were treated with a bolus of $5 \mathrm{mg}$ of ephedrine whenever systolic blood pressure was $20 \%$ lower than baseline values or below $100 \mathrm{mmHg}$. Complementary analgesia after the installation of the CSE consisted of $5 \mathrm{~mL}$ bolus of $0.125 \%, 0.25 \%$, or $0.5 \%$ bupivacaine with vasoconstrictor, according to the dilation of the uterine cervix.

The Apgar scores of the newborns in the $1^{\text {st }}, 5^{\text {th }}$, and $10^{\text {th }}$ minutes, defined by the neonatologist, were compared in both groups using the ANOVA, and a $p<0.05$ was considered significant. The relative risk of the fetuses of patients who received sufentanil to have Apgar scores below 7 in the $1^{\text {st }}, 5^{\text {th }}$, or $10^{\text {th }}$ minutes was determined. The relative risk was calculated by the ratio between the incidence of an Apgar score below 7 in the newborns exposed to sufentanil and the same incidence in those that were not exposed to this drug 9. The types of delivery in each group were compared using the Chi-square test.

\section{RESULTS}

Six hundred and ninety-eight anesthesias using the CSE technique were identified, but 63 patients (9\%) were excluded from the study because their charts were incomplete. Of the 635 valid anesthesias, 307 combined local anesthetic with sufentanil (SUF group) and 328 used local anesthetic alone (LA group).

Of the 635 blocks evaluated, 127 (20\%) were performed using the needle through the needle technique, performing the epidural puncture with a 16G Tuohy needle using the loss of resistance technique, and spinal anesthesia with a $27 \mathrm{G}$ (116 $\mathrm{mm}$, Whitacre) needle introduced through the epidural needle and introduction of the $18 \mathrm{G}$ epidural catheter. The remaining 508 CSE (80\%) were done using two punctures: 


\section{COMBINED SPINAL-EPIDURAL FOR LABOR ANALGESIA: DOES THE ADDITION OF SUFENTANIL TO THE LOCAL ANESTHETIC INFLUENCE APGAR SCORES OF THE NEWBORNS?}

spinal anesthesia with a $27 \mathrm{G}$ (90 $\mathrm{mm}$, Whitacre) needle, and the epidural puncture was done in the best space immediately above or below with a $16 \mathrm{G}$ needle (loss of resistance technique) and introduction of an $18 \mathrm{G}$ epidural catheter.

The SUF group was composed of 307 patients who received $0.5 \%$ hyperbaric bupivacaine $(2.5 \mathrm{mg})$ and sufentanil $(2.5 \mu \mathrm{g})$ for the spinal anesthesia. The LA group had 328 patients who received $0.5 \%$ hyperbaric bupivacaine $(5 \mathrm{mg})$ for the spinal anesthesia.

There were no differences in age between both groups; the mean age in the LA group was $23.69 \pm 5.56$ years and in the SUF group it was $23.05 \pm 5.68$ years ( $t$ test with $p=0.15$ ). There were no differences in weight between both groups: $69.4 \pm 11.2 \mathrm{~kg}$ in the LA group and $71.6 \pm 10.4 \mathrm{~kg}$ in the SUF group ( $t$ test with $p=0.42$ ).

The relative risk (RR) of the fetus of a woman who received sufentanil to have an Apgar score in the $1^{\text {st }}$ minute lower than 7 was 0.78 (95\% IC, 0.60 to 1.02 ) when compared to the fetuses who were exposed only to the local anesthetic. The relative risk remained below 1 for the Apgar scores in the $5^{\text {th }}$ minute ( $R R=0.43 / 95 \% \mathrm{IC}, 0.19$ to 0.99 ) and $10^{\text {th }}$ minute (RR =0) (Table I).

There were no significant differences in Apgar scores of both groups in the $1^{\text {st }}, 5^{\text {th }}$, and $10^{\text {th }}$ minutes (Table II).

Nineteen patients $(2.9 \%)$ presented persistent fetal bradycardia shortly after the CSE, and for this reason underwent cesarean sections. Among those patients, eight $(2,6 \%)$ belonged to the SUF group and 11 (3.3\%) to the LA group, which was not statistically significant.

As for the type of delivery, in the SUF group there were $23.4 \%$ cesarean sections, $54.1 \%$ forceps, and $22.5 \%$ normal deli-
Table I - Newborns with Apgar Scores Below 7 in the $1^{\text {st }}, 5^{\text {th }}$, and $10^{\text {th }}$ minutes

\begin{tabular}{lcc}
\hline Apgar $<7$ & SUF Group & LA Group \\
\hline $1^{\text {st }}$ minute & $34(11.1 \%)$ & $46(14 \%)$ \\
$5^{\text {th }}$ minute & $4(1.3 \%)$ & $10(3 \%)$ \\
$10^{\text {th }}$ minute & 0 & $4(1.2 \%)$ \\
Total $(\mathrm{n})$ & 307 & 328 \\
\hline
\end{tabular}

SUF - Group that received sufentanil associated with the local anesthetic; LA - Local anesthetic group.

veries. In the LA group, there were $25 \%$ cesarean sections, $50.3 \%$ forceps, and $24.7 \%$ normal deliveries (Table III), without statistically significant differences by the Chi-square test. Table IV shows the length of time from the CSE until delivery, the duration of anesthesia, incidence of hypotension in both groups, and the need to complement the blockade. There were statistically significant differences between the groups regarding the duration of anesthesia after the initial dose, with greater duration in the sufentanil group, as well as a decreased incidence of hypotension and decreased need for complementation of analgesia in the sufentanil group.

Five patients $(0.7 \%)$ had obstruction of the epidural catheter or failure of the complementation through the catheter; there was accidental puncture of the dura mater in six patients $(0.9 \%)$, and the patients presented headache due to spinal fluid hypotension, being treated with autologous blood patch. One patient $(0.16 \%)$ presented symptoms compatible with aseptic meningitis.

Table II - Mean and Mode of the Apgar Scores in the $1^{\text {st }}, 5^{\text {th }}$, and $10^{\text {th }}$ Minutes in the Sufentanil and Local Anesthetic Groups

\begin{tabular}{lccc}
\hline Apgar (mean \pm SD / mode) & SUF Group & LA Group & $p$ \\
\hline $1^{\text {st }}$ minute & $8.18 \pm 1.61 / 9$ & $7.77 \pm 1.82 / 9$ & 0.08 \\
$5^{\text {th }}$ minute & $9.29 \pm 0.73 / 9$ & $8.97 \pm 1.05 / 9$ & 0.35 \\
$10^{\text {th }}$ minute & $9.59 \pm 0.54 / 10$ & $9.40 \pm 0.88 / 10$ & 0.46 \\
\hline
\end{tabular}

SUF - Group that received sufentanil associated with the local anesthetic; LA - Local anesthetic group. $p-$ ANOVA.

Table III - Types of Deliveries in Both Groups

\begin{tabular}{lccc}
\hline Type of Delivery & SUF Group & LA Group & $\mathrm{p}$ \\
\hline Normal & $69(22.5 \%)$ & $81(24.7 \%)$ & $0.45^{\star}$ \\
Forceps & $166(54.1 \%)$ & $165(50.3 \%)$ & $0.35^{\star}$ \\
Cesarean section & $72(23.4 \%)$ & $82(25 \%)$ & $0.70^{*}$ \\
Total $(\mathrm{n})$ & 307 & 328 & 635 \\
\hline
\end{tabular}

SUF - Group that received sufentanil associated with the local anesthetic; LA - Local anesthetic group.

${ }^{*} p-$ Chi-square. 
CICARELLI, SILVA, FRERICHS ET AL.

Table IV - Differences Between Both Groups Regarding the Length of Time from CSE until Delivery, Duration of Anesthesia, Incidence of Hypotension, and Need of Complementation of Analgesia

\begin{tabular}{lccc}
\hline Characteristics & SUF Group (307) & LA Group (328) & $\mathrm{p}$ \\
\hline Length of time from CSE until delivery (min) & $70.1 \pm 35.3$ & $69.7 \pm 24.8$ & 0.77 \\
Duration of anesthesia (min) & $88.2 \pm 25.3$ & $66.4 \pm 17.3$ & $<0.01$ \\
Hypotension & $59(19 \%)$ & $138(42 \%)$ & $<0.01$ \\
Complementation & $84(27 \%)$ & $172(52 \%)$ & $<0.01$ \\
\hline
\end{tabular}

SUF - Group that received sufentanil associated with the local anesthetic; LA - Local anesthetic group.

\section{DISCUSSION}

This study did not confirm the negative influence of sufentanil, used in the CSE, on the Apgar scores of newborns.

An Apgar score below 7 is considered an indication of perinatal asphyxia by pediatricians, explaining the reason for the choice of this value to determine fetal distress ${ }^{9-11}$. The relative risk of the newborns exposed to sufentanil to present and Apgar score below 7 was below 1, which does not indicate an increased risk ${ }^{9}$. This result is confirmed by Lo WK et al. ${ }^{5}$ who also did not find differences in the evolution of the newborns after the subarachnoid administration of $10 \mu \mathrm{g}$ of sufentanil with $2.5 \mathrm{mg}$ bupivacaine when compared with 2.5 $\mathrm{mg}$ of bupivacaine alone. Another author ${ }^{4}$ reported that the use of fentanyl $(100 \mu \mathrm{g})$ in spinal anesthesia did not influence the evolution of the newborns. Vertommen et al. ${ }^{12}$ stated that sufentanil $(30 \mu \mathrm{g})$ used in epidural anesthesia could be detected in the plasma of up to $12 \%$ of newborns. However, those newborns did not show any changes in vitality. This is confirmed by Scherer et al. ${ }^{13}$, who used epidural sufentanil $(50 \mu \mathrm{g})$ and did not observe deleterious effects on the newborns.

Fetal bradycardia observed immediately after analgesia is frequently attributed to the use of opioids associated with the local anesthetic on CSE. There are several explanations: the fast relief of pain would decrease the concentration of plasma epinephrine ${ }^{14}$, the patient would lose the tocolytic effect of epinephrine, developing uterine hypertonia and fetal bradycardia ${ }^{8,14-16}$. D'Angelo et al. ${ }^{17}$ stated that the use of sufentanil is not associated with uterine hypertonia and that the fetal bradycardia would be secondary to maternal hypotension after the CSE. In our study, the prevalence of persistent fetal bradycardia, which was an indication for cesarean section, was of $2.9 \%$, while in the literature it varies from 5 to $8 \%{ }^{18}$. Although we did not observe a relationship between fetal bradycardia and the use of sufentanil, the number of patients with bradycardia in the SUF group $(2.6 \%)$ was smaller than in the LA group (3.3\%). This observation would support the affirmation of D'Angelo et al. as the most likely explanation for this effect.

The results demonstrated that CSE lasts longer when sufentanil is associated with the local anesthetic. This is corroborated by the studies of other authors, although the duration in our study was longer ${ }^{19}$. The group who underwent CSE only with local anesthetic also had greater prevalence of hypotension as soon as the block was performed, because the dose of local anesthetic in this group was greater than in the sufentanil group. Apparently, this did not influence Apgar scores, since hypotension was promptly corrected with ephedrine. The need for more complementation in the local anesthetic group is compatible with the shorter duration of the anesthesia observed in this group. The influence of this fact on Apgar scores of the newborns also seems unlikely, since the duration of anesthesia in the LA group was very close to the duration of the CSE until delivery. Therefore, despite the need for complementation being greater in the LA group, it happened close to delivery or shortly after, being treated with low doses of bupivacaine $(5 \mathrm{~mL}$ of $0.5 \%$ with vasoconstrictor).

The length of time from the beginning of CSE and the delivery was similar in both groups. This indicates that sufentanil is not responsible for a faster evolution of labor. There are controversial results in the literature that always compare CSE with the classic epidural anesthesia. Tsen et al. ${ }^{3}$ demonstrated a faster evolution of labor in the CSE group, which was not confirmed by Norris et al. ${ }^{18}$.

There were no differences between the techniques used for CSE regarding side effects. The prevalence of postpuncture headache was $0.9 \%$, which is comparable with the results of other authors, who reported prevalence varying from $0.82 \%{ }^{1}$ to $2.3 \%{ }^{4}$. We observed one case of aseptic meningitis among 635 patients evaluated $(0.16 \%)$. Wee et al. ${ }^{20}$ reported two cases among 1,500 patients evaluated $(0.13 \%)$. Some authors reported an increase in the number of aseptic meningitis after the introduction of the CSE technique ${ }^{1,12,20-22}$, especially when the needle through the needle technique is used. In the case observed in the present study, the needle through the needle technique was used for the CSE.

We can make a few critics about this study. Since it was a retrospective study, there might have been a lack of uniformity of the data recorded. Besides, every time a pediatrician reanimated a newborn with a low Apgar score in the first minute, he asked about the presence of opioids in the anesthesia. Therefore, there might have been a bias, i.e., pediatricians may have assigned lower Apgar scores to newborns 
whose mothers received sufentanil. However, this bias would tend to decrease the classification of the vitality of newborns exposed to sufentanil, leading to the conclusion of a negative influence of sufentanil on Apgar scores of newborns. This bias can be ignored, since that was not the conclusion of this study. Nonetheless, the presence of confounding variables is possible, i.e., other factor could have lowered Apgar scores. Any pregnant woman whose fetus presented altered vitality interpreted as fetal distress after the CSE underwent a cesarean section. Since the incidence of cesarean sections was similar in both groups, it was possible to conclude that the possibility of any confounding variable having jeopardized the results was minimal.

According to the results, it was not possible to attribute to sufentanil any changes in the Apgar scores of newborns, as well as any influence in fetal bradycardia observed after the CSE.

\section{REFERÊNCIAS - REFERENCES}

01. Cook TM - Combined spinal-epidural techniques. Anaesthesia, 2000;55:42-64.

02. Shaw IC, Birks RJS - A case of extensive block with the combined spinal-epidural technique during labour. Anaesthesia, 2001; 56:346-349.

03. Tsen LC, Thue B, Datta $S$ et al. - Is combined spinal-epidural analgesia associated with more rapid cervical dilation in nulliparous patients when compared with conventional epidural analgesia? Anesthesiology, 1999;91:920-925.

04. Collis RE, Baxandall ML, Srikantharajah ID et al. - Combined spinal epidural (CSE) analgesia: technique, management and outcome of 300 mothers. Int J Obst Anesth, 1994;3:75-81.

05. Lo WK, Chong JL, Chen LH — Combined spinal epidural for labour analgesia - duration, efficacy and side effects of adding sufentanil or fentanyl to bupivacaine intrathecally vs plain bupivacaine. Singapore Med J, 1999;40:639-643.

06. Abouleish A, Abouleish E, Camann W - Combined spinal-epidural analgesia in advanced labour. Can J Anaesth, 1994; 41:575-578.

07. Westmore MD - Epidural opioids in obstetrics - a review. Anaesth Intens Care, 1990;18:292-300.

08. Clarke VT, Smiley RM, Finster M - Uterine hyperactivity after intrathecal injection of fentanyl for analgesia during labor: a cause of fetal bradycardia? Anesthesiology, 1994;81:1083.

09. Greenberg RS, Daniels SR, Flanders WD et al. - Medical Epidemiology, $3^{\text {rd }}$ Ed, Nova York, McGraw-Hill, 2001;146-162.

10. Van De Velde M, Vercauteren $M$, Vandermeersch $E$ - Fetal heart rate abnormalities after regional analgesia for labor pain: the effect of intrathecal opioids. Reg Anesth Pain Med, 2001;26:257-262.

11. Nageotte MP, Larson D, Rumney PJ et al. - Epidural analgesia compared with combined spinal-epidural analgesia during labor in nulliparous women. N Engl J Med, 1997;337:1715-1719.

12. Vertommen JD - Opioids in combination with local anesthetics for epidural analgesia during labor. Eur J Obstetr Gynaecol Reprod Biol, 1995;(Suppl 59):S35-S38.

13. Scherer R, Holzgreve $W$ - Influence of epidural analgesia on fetal and neonatal well-being. Eur J Obstetr Gynaecol Reprod Biol, 1995; (Suppl 59):S17-S29.

14. Wong CA, Scavone BM, Peaceman AM et al. - The risk of cesarean delivery with neuraxial analgesia given early versus late in labor. N Engl J Med, 2005;352:655-665.
15. Van De Velde M, Teukens A, Vandermeersch E - Regional anesthesia and analgesia for labor and delivery. $\mathrm{N}$ Engl J Med, 2003;348:1818-1820.

16. Eisenach JC - Combined spinal-epidural analgesia in obstetrics. Anesthesiology, 1999;91:299-302.

17. D'Angelo R, Eisenach JC - Severe maternal hypotension and fetal bradycardia after a combined spinal epidural anesthetic. Anesthesiology, 1997;87:166-168.

18. Norris MC, Fogel ST, Conway-Long C - Combined spinalepidural versus epidural labor analgesia. Anesthesiology, 2001; 95:913-920.

19. Yamaguchi ET, Carvalho JC, Fonseca US et al. - Sufentanil subaracnóideo associado à bupivacaína hiperbárica para analgesia de parto: é possível reduzir a dose do opióide? Rev Bras Anestesiol, 2004; 54:145-152.

20. Wee M, Morgan BM, Collis RE et al. - Meningitis after combined spinal-extradural anaesthesia in obstetrics. Br J Anaesth, 1995; 74:351-353.

21. Oliveira AS, Côrtes CAF - Meningite após técnica combinada para analgesia de parto. Relato de caso. Rev Bras Anestesiol, 2002; 52:515-516.

22. Harding SA, Collis RE, Morgan BM - Meningitis after combined spinal-extradural anaesthesia in obstetrics. Br J Anaesth, 1994; 73:545-547.

\section{RESUMEN}

Cicarelli DD, Silva RV, Frerichs E, Pagnocca ML - Bloqueo Combinado para Analgesia de Parto: ¿La Adición de Sufentanil al Anestésico Local Influye en el Apgar de los Recién Nacidos?

JUSTIFICATIVA Y OBJETIVOS: El bloqueo combinado (BC) es una técnica muy utilizada en anestesia obstétrica. Sin embargo no existe en la literatura una estandarización con relación a la técnica, dosis y anestésicos utilizados, además de la controversia sobre la posibilidad de la adición del opioide al anestésico local causar una bradicardia fetal y la alteración de su vitalidad. El objetivo de este estudio fue identificar las técnicas y anestésicos utilizados en el Servicio de Anestesiología del Hospital Universitario de la Universidade de São Paulo (USP) y evaluar si la utilización de sufentanil asociado al anestésico local en el BC altera el Apgar de los recién nacidos.

MÉTODO: Se analizaron las fichas de anestesia en que se realizaron BC para la analgesia de parto durante 12 meses en el Hospital Universitario de la USP. Se registraron el uso y la dosis de sufentanil, la vía de parto utilizada y las puntuaciones de Apgar del $1^{\circ}, 5^{\circ}$ y $10^{\circ}$ minutos de los recién nacidos.

RESULTADOS: De los 635 BC evaluados, 307 utilizaron sufentanil y anestésico local (Grupo SUF) y 328, solo anestésico local (Grupo AL). Ciento veinte y siete (20\%) fueron realizados a través de la técnica de aguja por dentro de aguja y los otros 508 (80\%) realizados por la técnica dos punciones. No se verificó diferencia entre el Apgar de los grupos estudiados en el $1^{\circ}, 5^{\circ}$ y $10^{\circ}$ minutos.

CONCLUSIONES: El sufentanil utilizado en el bloqueo combinado no alteró el Apgar de los recién nacidos. 